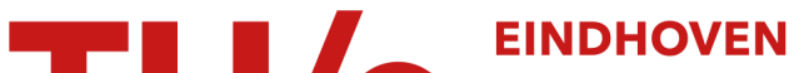 UNIVERSITY OF TECHNOLOGY
}

\section{Capacity of weakly (d,k)-constrained sequences}

\section{Citation for published version (APA):}

Schouhamer Immink, K. A., \& Janssen, A. J. E. M. (2000). Capacity of weakly (d,k)-constrained sequences. In 2000 IEEE International Symposium on Information Theory (pp. 144). Institute of Electrical and Electronics Engineers. https://doi.org/10.1109/ISIT.2000.866436

DOI:

10.1109/ISIT.2000.866436

Document status and date:

Published: 01/01/2000

\section{Document Version:}

Publisher's PDF, also known as Version of Record (includes final page, issue and volume numbers)

\section{Please check the document version of this publication:}

- A submitted manuscript is the version of the article upon submission and before peer-review. There can be important differences between the submitted version and the official published version of record. People interested in the research are advised to contact the author for the final version of the publication, or visit the $\mathrm{DOI}$ to the publisher's website.

- The final author version and the galley proof are versions of the publication after peer review.

- The final published version features the final layout of the paper including the volume, issue and page numbers.

Link to publication

\section{General rights}

Copyright and moral rights for the publications made accessible in the public portal are retained by the authors and/or other copyright owners and it is a condition of accessing publications that users recognise and abide by the legal requirements associated with these rights.

- Users may download and print one copy of any publication from the public portal for the purpose of private study or research.

- You may not further distribute the material or use it for any profit-making activity or commercial gain

- You may freely distribute the URL identifying the publication in the public portal.

If the publication is distributed under the terms of Article 25fa of the Dutch Copyright Act, indicated by the "Taverne" license above, please follow below link for the End User Agreement:

www.tue.nl/taverne

Take down policy

If you believe that this document breaches copyright please contact us at:

openaccess@tue.nl

providing details and we will investigate your claim. 


\section{Capacity of weakly $(d, k)$-constrained sequences}

\author{
Kees A. Schouhamer Immink \\ Institute for Experimental \\ Mathematics, Ellernstrasse 29, \\ 45326 Essen, Germany. \\ immink@exp-math.uni-essen.de
}

Augustus J.E.M. Janssen

Philips Research Laboratories,

WY 81, Prof. Holstlaan 4, 5656

AA Eindhoven, The Netherlands.

a.j.e.m.janssen @philips.com

\begin{abstract}
In the presentation we find an analytic expression for the maximum of the normalized entropy $-\sum_{i \in T} p_{i} \ln p_{i} / \sum_{i \in T} i p_{i}$ where the set $T$ is the disjoint union of sets $S_{n}$ of positive integers that are assigned probabilities $P_{n}, \sum_{n} P_{n}=1$. This result is applied to the computation of the capacity of weakly $(d, k)$-constrained sequences that are allowed to violate the $(d, k)$-constraint with small probability.
\end{abstract}

\section{Problem description and Results}

Let $T$ be a set of positive integers, and assume that $T$ is the disjoint union of a (finite or infinite) number of nonempty sets $S_{n}, n \in M$. Also assume that there are given numbers $P_{n} \geq 0, n \in M$, with $\sum_{n} P_{n}=1$. We show the following result.

Theorem: The maximum of

$$
H:=\frac{-\sum_{i \in T} p_{i} \ln p_{i}}{\sum_{i \in T} i p_{i}}
$$

(In : natural logarithm) under the constraints that $p_{i} \geq 0$, $\sum_{i \in S_{n}} p_{i}=P_{n}, n \in M$, equals $z_{0}$, where $z_{0}>0$ is the unique solution $z$ of the equation

$$
-\sum_{n \in M} P_{n} \ln Q_{n}(z)=-\sum_{n \in M} P_{n} \ln P_{n}
$$

with for $z>0$

$$
Q_{n}(z):=\sum_{i \in S_{n}} e^{-i z}, \quad n \in M
$$

Moreover, the optimal $p_{i}$ are given by

$$
p_{i}=\frac{P_{n}}{Q_{n}\left(z_{0}\right)} e^{-i z_{0}}, \quad i \in S_{n}, n \in M
$$

and for these $p_{i}$ we have that

$$
\sum_{i \in T} i p_{i}=\frac{d}{d z}\left[-\sum_{n \in M} P_{n} \ln Q_{n}(z)\right]\left(z_{0}\right) .
$$

As an application of this result we consider weakly constrained $(d, k)$ sequences [1]. A binary $(d, k)$-constrained sequence has by definition at least $d$ and at most $k$ 'zeros' between consecutive 'ones'. Weakly constrained codes produce sequences that violate the specified constraints with a small probability. It is argued that if the channel is not free of errors, it is pointless to feed the channel with perfectly constrained sequences. A $(d, k)$-constrained sequence can be thought to be composed of 'phrases' $10^{i}$, $d \leq i \leq k$, where $0^{i}$ means a series of $i$ 'zeros'. In order to compute the channel capacity, i.e. the maximum $z_{0} / \ln 2$ of the entropy $H / \ln 2$, we define

$$
\begin{aligned}
T & =\{1, \ldots, d\} \cup\{d+1, \ldots, k+1\} \\
\cup & \{k+2, k+3, \ldots\}=: S_{1} \cup S_{2} \cup S_{3},
\end{aligned}
$$

where $d=0,1, \ldots$, and $k=d+1, d+2, \ldots$ are given, and we compute the capacity for the case that the probabilities $P_{1}, P_{3}$ assigned to the sets $S_{1}, S_{3}$ are both small. Clearly, the quantities $P_{1}$ and $P_{3}$ denote the probabilities that phrases are transmitted that are either too short or too long, respectively. We find that the familiar capacities of $(d, k)$-constrained sequences [2] are approached from above as $P_{1}, P_{3} \rightarrow 0$ with an error $A\left(P_{1} \ln P_{1}+P_{3} \ln P_{3}\right)$, where we can evaluate the $A$ explicitly. We obtain a similar result for the case that $T$ is as in (6) with $S_{1}, S_{3}$ merged into a single set $S_{1} \cup S_{3}$. Further results are published in [3].

\section{Conclusions}

We have presented an analytic expression for the maximum of the normalized entropy $-\sum_{i \in T} p_{i} \ln p_{i} / \sum_{i \in T} i p_{i}$ under the condition that $T$ is the disjoint union of sets $S_{n}$ of positive integers that are assigned probabilities $P_{n}, \sum_{n} P_{n}=1$. We computed the capacity of weakly $(d, k)$-constrained sequences that are allowed to violate the $(d, k)$-constraint with given probability.

\section{References}

[1] K.A.S. Immink, 'Weakly Constrained Codes', Electronics Letters, vol. 33, no. 23, pp. 1943-1944, Nov. 1997.

[2] K.A.S. Immink, Codes for Mass Data Storage Systems, Shannon Foundation Publishers, Eindhoven, The Netherlands, 1999.

[3] A.J.E.M. Janssen and K.A.S. Immink, 'An entropy theorem for computing the capacity of weakly $(d, k)$ constrained sequences', IEEE Trans. Inform. Theory, vol. IT-46, no. 5, pp., May 2000. 